\title{
Jean Ouédraogo, Maryse Condé et Ahmadou Kourouma. Griots de l'indicible
}

\section{Francesca Torchi}

\section{Q OpenEdition}

1 Journals

\section{Edizione digitale}

URL: http://journals.openedition.org/studifrancesi/28138

DOI: 10.4000/studifrancesi.28138

ISSN: 2427-5856

\section{Editore}

Rosenberg \& Sellier

\section{Edizione cartacea}

Data di pubblicazione: 31 décembre 2006

Paginazione: 644-645

ISSN: 0039-2944

\section{Notizia bibliografica digitale}

Francesca Torchi, «Jean Ouédraogo, Maryse Condé et Ahmadou Kourouma. Griots de l'indicible », Studi

Francesi [Online], 150 (L | III) | 2006, online dal 30 novembre 2015, consultato il 08 novembre 2020.

URL : http://journals.openedition.org/studifrancesi/28138; DOI : https://doi.org/10.4000/

studifrancesi.28138

Questo documento è stato generato automaticamente il 8 novembre 2020.

\section{(c)}

Studi Francesi è distribuita con Licenza Creative Commons Attribuzione - Non commerciale - Non opere derivate 4.0 Internazionale. 


\title{
Jean Ouédraogo, Maryse Condé et Ahmadou Kourouma. Griots de l'indicible
}

\author{
Francesca Torchi
}

\section{NOTIZIA}

JEAn oUÉDRAogo, Maryse Condé et Ahmadou Kourouma. Griots de l'indicible, New York, Peter Lang, 2004, pp. 180.

1 Attraverso uno studio comparato delle opere dello scrittore senegalese Ahmadou Kourouma e della scrittrice guadalupeana Maryse Condé - autrice di una serie di romanzi dedicati all'Africa, in cui ha vissuto e lavorato -, questo saggio si propone di mettere in luce le caratteristiche distintive del romanzo storico africano. L'autore Ouédraogo fa emergere dalla propria analisi alcune figure e temi chiave come il Fuciliere e l'Interprete nelle rappresentazioni dell'Africa Occidentale prima e dopo le Indipendenze, individuando in essi i simboli di un intero mondo. Il discorso si sviluppa poi attorno al popolo mandingo, alle sue modalità discorsive e alla figura del griot, detentore del patrimonio di racconti e di miti tradizionali e porta-parola di un immaginario ben preciso. Il volume si chiude con le interviste a Maryse Condé e Ahamadou Kourouma che riflettono sulla parola e sul ruolo dello scrittore nella società.

2 Uno degli aspetti di maggiore interesse di questo testo, che si occupa della storia dell'Africa, delle modalità e della possibilità di raccontarla, è senz'altro la scelta degli autori analizzati. Ouédraogo si propone infatti di valorizzare oggi l'Africa come punto d'incontro, come esperienza comune e come oggetto letterario attraverso il dialogo fra le opere di due scrittori di discendenza africana, cementando il legame tra Africa e Antille. L'autore sostiene infatti che nel periodo successivo alla Négritude esistono dei caratteri specifici di contatto tra le espressioni letterarie caraibiche e africane, dei 
momenti di «conjonctions, disjonctions, et de dissensions internes les émaillant et le définissant» (p.1), che ribadiscono un rapporto di continuità pur nell'autonomia. 